\title{
Use of electron microscopy in examination of faeces and rectal and jejunal biopsy specimens
}

\author{
G M M Connolly, D S Ellis, J E Williams, G Tovey, B G Gazzard
}

\begin{abstract}
The stools and rectal biopsy specimens of 44 patients with AIDS and diarrhoea were examined by culture, light microscopy, and electron microscopy. In 13 patients examination of rectal biopsy material and faecal samples showed no pathogen, but in two of these, microsporidiosis was found by electron microscopical examination of jejunal biopsy specimens. This organism was also identified electron microscopically in one of the further five jejunal biopsy samples taken from patients with a known cause of diarrhoea. Blastocystis hominis infection was identified electron microscopically in six patients, all of whom had cryptosporidiosis additionally seen by light microscopy. Four of these six patients remained well for long periods, with only moderate diarrhoea, and follow up showed no evidence of blastocystis infection. In only four of 11 patients found to have cryptosporidium in their stools at light microscopy were organisms found at electron microscopy. Viral inclusions were only identified at electron microscopy in one of 10 patients with an opportunistic viral infection seen at light microscopy (cytomegalovirus $\mathbf{n}=7$, herpes simplex virus $\mathbf{n}=3$ ). No additional viral pathogens were detected in either stools or rectal biopsy material by electron microscopy.

It is concluded that routine electron microscopic examination of stool samples or rectal biopsy material taken from patients with AIDS and diarrhoea is unnecessary and does not increase the yield of potential pathogens compared with standard microbiological techniques and histology.
\end{abstract}

Department of Medicine, Westminster Hospital, Dean Ryle Street, Horseferry Road, London SW1 G M M Connolly B G Gazzard

Electron Microscopy and Histopathology Unit, London School of Hygiene and Tropical Medicine

D S Ellis

J E Williams

G Tovey

Correspondence to Dr B G Gazzard

Accepted for publication

21 November 1990
In some patients with AIDS and diarrhoea, no pathogenic organism can be detected in stools or in rectal biopsy specimens. ${ }^{1}$ The pathogenesis of diarrhoea in such patients is of considerable interest: possibilities include infection of gut mucosal cells with the human immunodeficiency virus (HIV), ${ }^{2}$ neuronal damage in the gut wall, ${ }^{3}$ or thirdly, a pathogen such as Microsporidium or a viral infection undetected by standard microbiological techniques (Abstract presented at the Fifth International Conference on AIDS, Montreal, 1989).

The purpose of this paper was to determine the value of electron microscopy in detecting unsuspected pathogens in HIV antibody positive patients with diarrhoea, particularly those in whom no microbiological cause had been found by routine methods.

The 44 patients in this study were all HIV antibody positive by two different methods ${ }^{4}$ and had had diarrhoea (at least three liquid stools every 24 hours) for longer than a month. All belonged to group IV subclass A or C according to the Centers for Disease Control Classification System for AIDS.

One hundred consecutive patients presenting between March and July 1989 were screened for diarrhoea by microbiological examination of stools and light microscopic examination of rectal biopsy material. The first 35 of these patients (group I) were included in this study whatever the results of the screening tests. Of the subsequent 65 patients, only the nine (group II) in whom no potential pathogen was uncovered by routine screening were included.

All patients in this study had stool samples and rectal biopsy specimens examined by electron microscopy. It was not thought ethical to perform jejunal biopsies on all patients, but they were examined by electron microscopy in 18. These included the 13 patients (four from group I) who underwent the procedure for diagnostic purposes as no other pathogen had been uncovered, and a further five patients (all with cytomegalovirus infection) who had had a biopsy as part of routine investigations for coincident upper abdominal dyspepsia.

All faecal samples were cultured routinely and examined for ova, cysts, and parasites. They were stained by a modified ZiehlNeelsen method with concentration for Cryptosporidium. ${ }^{6}$ The faeces were further processed for mycobacterial species by inoculation on to a Lowenstein-Jensen slope and into Kirschner medium, and these were examined weekly for 10 weeks.

Jejunal biopsy material was obtained by a Watson capsule attached to the end of a flexible gastroscope and positioned beyond the fourth part of the duodenum, under direct vision.

Rectal biopsy samples were obtained from at least two sites from all patients during rigid sigmoidoscopy. The material was divided for electron microscopic and light microscopic examination.

Jejunal and rectal biopsy specimens were fixed in $15 \%$ unbuffered formol saline and processed using a routine paraffin wax system with vacuum impregnation. Sections were cut 
Table 1 Final cause of diarrhoea in 44 patients

\begin{tabular}{|c|c|c|c|c|}
\hline Final diagnosis $(n=)$ & Bacteriology & Histology & Elect & ron microscopy \\
\hline Cryptosporidium (7) & 7 & 3 & \multirow{2}{*}{\multicolumn{2}{|c|}{ Cryptosporidium seen in 4}} \\
\hline Cryptosporidium (4) and cytomegalovirus & 4 & 4 & & \\
\hline $\begin{array}{l}\text { Cytomegalovirus (2) } \\
\text { Herpes simplex virus (2) } \\
\text { Mycobacterium avium intracellulare (1) } \\
\text { Candida (1) } \\
\text { Non-Hodgkin's lymphoma (2) }\end{array}$ & $\begin{array}{l}\overline{-} \\
\overline{1} \\
1 \\
-\end{array}$ & $\begin{array}{l}3 \\
2 \\
1 \\
1 \\
2\end{array}$ & $\begin{array}{l}3 \\
1 \\
1 \\
1 \\
2\end{array}$ & Preneoplastic changes \\
\hline Bacterial infection (5) & $\begin{cases}1 & \text { Campylobacter } \\
4 & \text { Salmonella species }\end{cases}$ & _- & 3 & Bacterial infection \\
\hline $\begin{array}{l}\text { Giardia lamblia (6) } \\
\text { Microsporidia (2) } \\
\text { Microsporidia + CMV (1) } \\
\text { No pathogen (11) }\end{array}$ & $\begin{array}{l}4 \\
- \\
- \\
-\end{array}$ & $\begin{array}{l}4 \\
\overline{1} \mathrm{CMV}\end{array}$ & $\begin{array}{l}1 \\
2 \\
1 \\
-\end{array}$ & $\begin{array}{l}\text { on jejunal biopsy } \\
\text { on jejunal biopsy }\end{array}$ \\
\hline
\end{tabular}

at $5 \mu \mathrm{m}$, with at least three levels being taken. Haematoxylin and eosin and Ziehl-Neelsen stains were performed routinely. Cytomegalovirus (CMV) inclusion bodies were sought in all sections and confirmed using immunoperoxidase techniques suitable for paraffin wax sections. ${ }^{7}$

Severe inflammation was defined as a pronounced inflammatory infiltration in the lamina propria.

Electron microscopy was carried out on specimens fixed in glutaraldehyde (faecal material was embedded in $2 \%$ agar), post-fixed in osmium tetroxide, and after dehydration and embedding in Araldite, stained with lead citrate and uranyl acetate.

\section{Results}

In the whole series of 44 patients, electron microscopic screening yielded only nine additional pathogens. In six patients Blasto- cystis hominis infection was found in stool samples together with cryptosporidiosis, and in three patients microsporidial infection of jejunal biopsy material was uncovered, which was in addition to cytomegalovirus colitis in one case (table 1).

Two potential pathogens (microsporidial infection in both cases) were uncovered by electron microscopy in the 13 patients in whom no pathogen was found by routine microbiological screening of stools or light microscopic examination of rectal histological sections.

\section{MICROBIOLOGY}

Microbiological examination of the stools was the single most useful investigation that identified all the cases of cryptosporidial infection $(n=11)$ and four of the six cases of giardiasis. Two other opportunistic pathogens presumed to have caused the diarrhoea (Candida and Mycobacterium avium intracellulare [MAI])
Figure 1 Blastocystis hominis organism identified in stools of patients by electron microscopy.

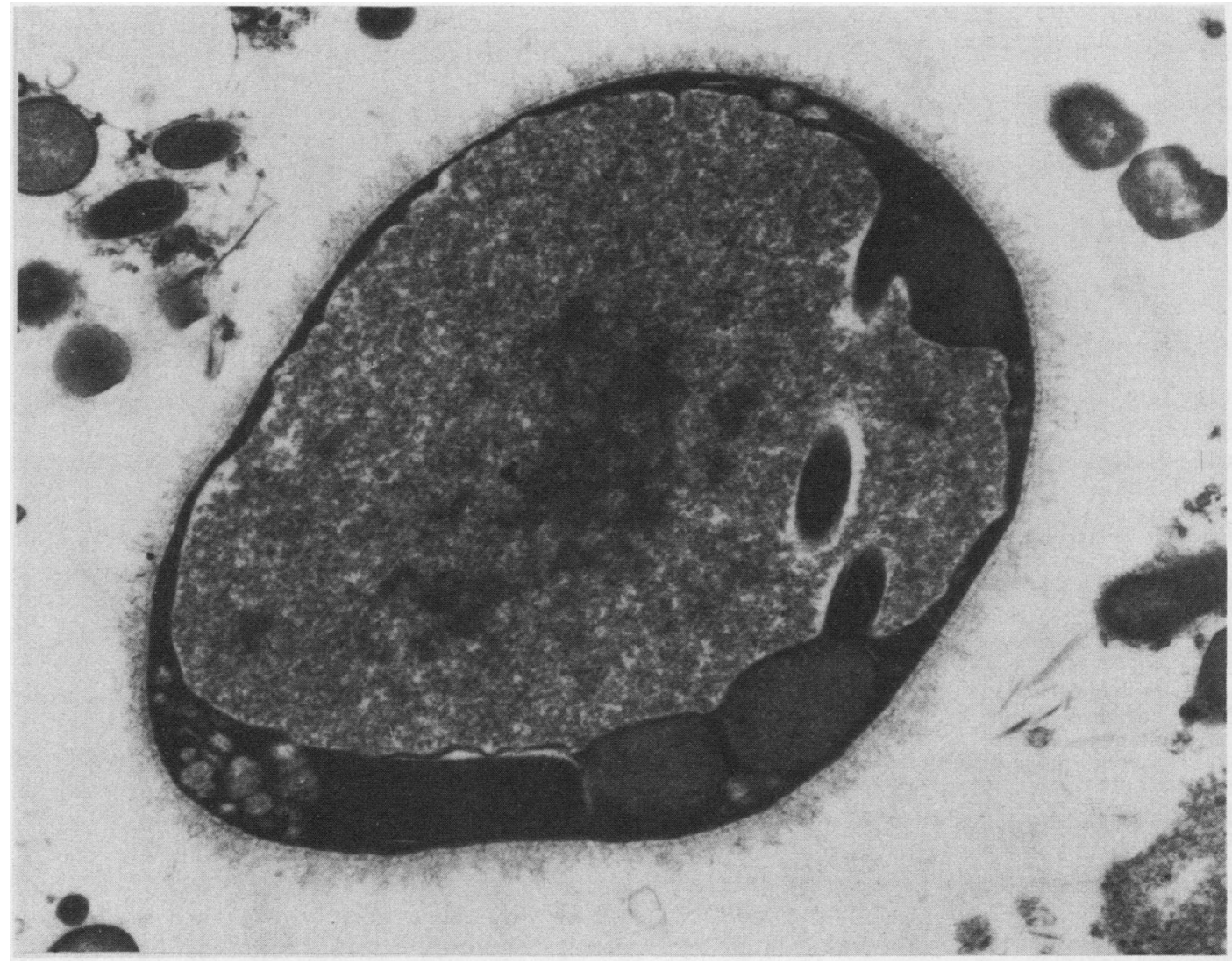


Table 2 Clinical features of 11 patients with cryptosporidiosis; six with blastocystis infection in addition

\begin{tabular}{|c|c|c|c|c|c|c|}
\hline \multirow{2}{*}{$\begin{array}{l}\text { Case } \\
\text { No }\end{array}$} & \multicolumn{2}{|c|}{ Electron microscopy } & \multirow{2}{*}{$\begin{array}{l}\text { Weight } \\
\text { loss at } \\
\text { presentation (kg) }\end{array}$} & \multirow{2}{*}{$\begin{array}{l}\text { Volume of } \\
\text { diarrhoea } \\
m l / 24 h\end{array}$} & \multirow{2}{*}{$\begin{array}{l}\text { Total CD4 } \\
\text { cells } \\
\times 10^{9} / l\end{array}$} & \multirow{2}{*}{$\begin{array}{l}\text { Survival } \\
\text { (months) }\end{array}$} \\
\hline & $B$ hominis & Cryptosp ${ }^{\star}$ & & & & \\
\hline 1 & + & - & 5 & 2500 & 20 & $5 t$ \\
\hline 2 & + & - & 15 & 1000 & 250 & 17 \\
\hline 3 & + & - & 3 & 800 & 200 & 18 \\
\hline 4 & + & - & 2 & 500 & 200 & 18 \\
\hline 5 & + & - & 2 & 500 & 150 & 18 \\
\hline 6 & + & + & 5 & 1000 & 30 & $9 \dagger$ \\
\hline 7 & - & + & 8 & 2500 & 20 & $3+$ \\
\hline 8 & - & + & 5 & 1500 & 45 & 12 \\
\hline 9 & - & + & 12 & 2000 & 20 & $9+$ \\
\hline 10 & - & - & 10 & 1500 & 30 & 7 \\
\hline 11 & - & - & 3 & 500 & 30 & 18 \\
\hline
\end{tabular}

*All these patients had cryptosporidiosis identified by light microscopical examination of stool samples.

Figure 2 Three Microsporidian meronts at an early stage of development lying beneath the duodenal microvilli of a patient with AIDS. and five non-opportunistic pathogens (Salmonella and Campylobacter species) were identified by stool culture (table 1 ).

LIGHT MICROSCOPICAL EXAMINATION OF RECTAL BIOPSY SPECIMENS

Light microscopical examination of rectal biopsy specimens was of most value in identifying opportunistic viral infection and confirming the diagnosis of tumour in two patients. Viral colitis was diagnosed in nine patients; cytomegalovirus (CMV) inclusions were seen in seven (four of whom also had cryptosporidium infection), and herpes simplex inclusions were identified in two.

Light microscopical examination failed to detect evidence of cryptosporidium in four of the 11 patients where this organism was identified in the stools, and did not discover any other patients with this infection.

Severe non-specific rectal inflammation was always present with viral colitis and bac- teriological infection but was absent from those with cryptosporidiosis, microsporidiosis, or no identified pathogen.

\section{ELECTRON MICROSCOPICAL EXAMINATION}

Electron microscopical examination of stools, rectal, or jejunal biopsy material showed $B$ hominis infection in the stools of six patients (fig 1). In all of these cryptosporidium had previously been identified by standard techniques and by electron microscopy in one. Four of these six patients remained relatively well despite lack of specific treatment and two died of overwhelming cryptosporidial infection (table 2). The organism could no longer be identified in the stools of three of the four surviving patients between three and six months later. The fourth patient was lost to follow up. There was no tendency for patients with blastocystis in addition to cryptosporidium to have more severe clinical manifestations (table 2).

Microsporidial infection was diagnosed by electron microscopical examination of jejunal biopsy samples in three patients (fig 2) and in two was the only potential pathogen. All three patients had stool volumes in excess of $1 \mathrm{l} /$ day and one died within two weeks of diagnosis; the other has been lost to follow up. The third remains seriously ill with CMV colitis.

In the two cases of lymphoma diagnosed by light microscopy bizarre nuclei in the lamina propria and excessive lipids in the mitochondria suggested neoplastic change.

Electron microscopical examination of rectal biopsy material did not diagnose any additional patients with cryptosporidial infection. In only four of the 11 patients diagnosed by light microscopy was there electron microscopical

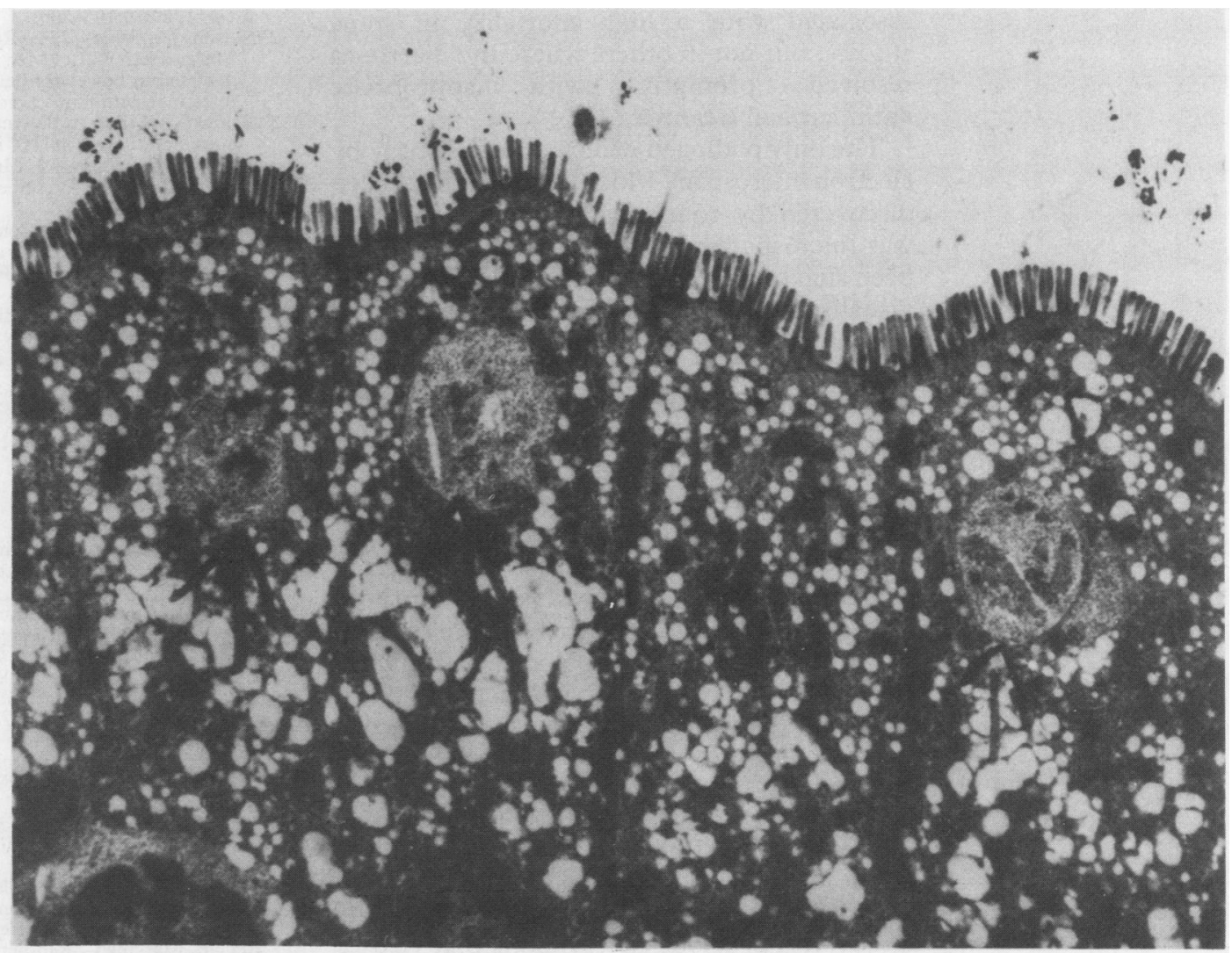


evidence of infection on rectal biopsy in three and in faecal material in one.

No viral pathogens were found in the faecal samples of the 44 patients. Viral inclusions were only seen in the rectal biopsy specimen in one patient who was known to have herpes simplex colitis.

\section{Discussion}

The range of causes of diarrhoea in these 44 HIV positive patients is similar to that of other published studies. ${ }^{1}$ Unfortunately, the addition of electron microscopy of stool samples and rectal biopsy material to standard investigation only yielded one pathogen of dubious clinical importance- $B$ hominis. Electron microscopic examination of a small number of jejunal biopsy samples, however, did show microsporidial infection in three patients.

Blastocystis hominis can be identified readily by light microscopical examination of stool samples when Field's stain is used. ${ }^{8}$ This has not been done routinely in our laboratory, but the high prevalence of blastocystis infection uncovered indicates the need to reconsider this policy. Field's stain was not used in this study as blastocystis infection was only discovered when all the stool samples were examined by electron microscopy in one batch. $B$ hominis carriage was confined to those patients who had cryptosporidial infection. The presence of $B$ hominis in these patients was of dubious pathogenic importance. The patients did not have a more severe clinical course than those with cryptosporidiosis alone. None received specific treatment, and three of the four surviving patients had no evidence of blastocystis infection at follow up, but had cryptosporidium as a cause for continuing diarrhoea. Blastocystis carriage in diarrhoea has been associated with a high mortality in some studies, but not in others where the diarrhoea resolved promptly with appropriate antimicrobial treatment. ${ }^{910}$

The only pathogen detected in this study by electron microscopy which could not have been discovered by routinely available techniques was microsporidium, although it has recently been suggested that even this organism may be visualised using thin plastic (resin) sections of jejunal biopsy specimens examined at electron microscopy. There is no positive proof that microsporidial infection produces diarrhoea, but it has only been found so far in symptomatic HIV positive patients in whom there are associated abnormalities of villus architecture which may produce diarrhoea. Furthermore, it seems to be particularly common in patients in whom no other cause for diarrhoea can be found. Thus although it was only seen in one of 100 jejunal biopsy specimens taken from HIV positive patients with a variety of known causes for diarrhoea, ${ }^{11}$ it was found in $30 \%$ of a group of patients from New York in whom other causes for diarrhoea had been excluded (Abstract presented at the Fifth International Conference on AIDS, Montreal, 1989).

The lack of detection of additional viral pathogens in faecal material from our patients agrees with previous observations that viruses usually identified by electron microscopy, such as rotavirus, have not been seen in HIV positive patients as a cause of diarrhoea (Abstract presented at the Fifth International AIDS Conference, Montreal, 1989). ${ }^{12}$ Other studies using immune electron microscopy techniques have shown entero viruses in up to $9 \%$ of HIV positive patients with AIDS, but this was not more common in patients who had diarrhoea. ${ }^{13}$

The optimal sequence of investigations for diarrhoea in HIV positive patients is gradually becoming clear. We have previously shown that the sensitivity of microbiological examination of stools and histological examination of rectal biopsy specimens combined is in excess of $90 \%$, with a high positive predictive value. ${ }^{14}$ This confirms the findings of French studies ${ }^{15}$ which showed that the single most useful test was stool examination followed by microbiological examination of fluid obtained during duodenal aspiration and that the sensitivity for detection of cytomegalovirus infection was improved by examination of rectal biopsy specimens. We believe that duodenal intubation is a relatively uncomfortable technique and should be reserved for patients in whom no pathogen is uncovered by routine microbiological examination of stools or histological examination of rectal biopsy specimens. If other studies confirm the high prevalence of microsporidiosis in patients in whom no other pathogen is found, examination of jejunal biopsy material would also become an important investigation. It would be helpful to ascertain whether duodenal pinch biopsy specimens, which are much easier to obtain, also provide evidence of this infection, and whether examination by light microscopy can be a sensitive technique for detection.

1 Connolly GM, Shanson D, Hawkins DA, HarcourtWebster JN, Gazzard BG. Non-cryptosporidial diarrhoea in human immunodeficiency virus (HIV) infected patients. Gut 1989;30:195-200.

2 Nelson JA, Wiley CA, Reynolds-Kohler C, Reese CE, Margaretten W, Levy JA. Human immunodeficiency virus detected in bowel epithelium from patients with gastrointestinal symptoms. Lancet 1988;i:259-62.

3 Griffin GE, Miller A, Bateman P. Damage to jejunal intrinsic autonomic nerves in HIV infection. AIDS 1988;2:379-82.

4 autonomic nerves in HIV infection. AIDS1988;2:379-82. III/LAV assays for screening and confirmation testing? Lancet 1985;ii:873-7.

5 Centers for Disease Control: Revision of the CDC surveillance definition for acquired immunodeficiency syndrome. Morbid Mortal Weekly Rep 1987;(suppl 36):15: 35-155.

6 Garcia LS, Bruckner DA, Brewer TC, Shimizu RL. Techniques for the recovery and identification of cryptosporidium oocytes from stool specimens. J Clin Microbiol Infect Dis 1987;8:235-44.

7 Francis ND, Boylston AW, Roberts AHG, Parkin JM, Pinching AJ. Cytomegalovirus in gastrointestinal tracts of patients infected with HIV I or AIDS, $J$ Clin Pathol 1989;42:1055-64.

8 Moody AH, Fleck SL. Versatile Field's stain. J Clin Pathol 1985;38:842-3.

9 Kain KC, Noble MA, Freeman HJ, Barteluk RL. Epidemiology and clinical features associated with Epidemiology and clinical features associated with Dis 1987;8:235-44.

10 Russo AR, Stone SL, Taplin ME, Snapper HJ, Doern GV. Presumptive evidence for Blastocystis hominis as a cause of colitis. Arch Int Med 1984;148:1064.

11 Canning EU, Hollister WS. Enterocytozoan bieneusi (microsporidia) prevalence and pathogenicity in AIDS patients. Trans Roy Soc Trop Med Hyg 1990;84:181-6.

12 Smith PD, Lane C, Gelvie J, et al. Intestinal infections in patients with the acquired immunodeficiency syndrome (AIDS). Ann Intern Med 1988;108:328-33.

13 Kaljot KT, Ling JP, Gold JW, et al. Prevalence of acute enteric viral pathogens in acquired immunodeficiency syndrome patients with diarrhoea. Gastroenterology 1989 ; 97:1031-2.

14 Connolly GM, Forbes A, Gleeson J, Gazzard BG. The value of barium enema and colonoscopy in patients infected with
the human immunodeficiency virus. AIDS 1990;4:687-9.

15 Rene E, Marchie C, Requier B, et al. Intestinal infections in patients with acquired immunodeficiency syndrome: A prospective study of 132 patients. Dig Dis Sci 1989; prospective
34:773-80. 